\title{
Pernicious Anaemia among Asians in Singapore
}

\author{
F. J. JAYARATNAM,* M.B., B.S., M.R.A.C.P. ; CHENG SIANG, SEAH, $†$ M.D., M.R.C.P.ED. \\ J. L. DA COSTA, $\ddagger$ M.B., B.S., M.R.C.P.ED., M.R.C.P.GLASG. \\ KHENG-KHOO, TAN,§ M.B., B.S., D.C.P., DIP.PATH., M.C.PATH. ; W. O'BRIEN,\| O.B.E., M.D., F.R.C.P.
}

Brit. med. F., 1967, 3, 18-20

In an investigation of 40 consecutive cases of megaloblastic anaemia admitted to the Medical Unit, Thomson Road General Hospital, Singapore, from mid-1962 until the end of 1965, six patients (four Chinese and two Indians) were found to fulfil all the criteria for a diagnosis of pernicious anaemia. All six had megaloblastic marrows, histamine-fast (maximal stimulation) achlorhydria, very low serum vitamin- $B_{12}$ levels, and an inability to absorb this vitamin orally, this inability being corrected by the addition of intrinsic factor. These cases are worth reporting, because pernicious anaemia has not hitherto been reported in Singapore and Malaysia, and also because of the paucity of reports of pernicious anaemia in Chinese and Indians.

\section{Methods}

The following investigations were carried out:

Haematological investigations included an estimation of the haemoglobin, total red and white cell, platelet, and reticulocyte counts, packed cell volume, mean corpuscular volume, mean corpuscular haemoglobin concentration, and examination of smears of the peripheral blood film and bone marrow. Serum vitamin $B_{12}$ and folic acid assays were carried out in the Hammersmith Postgraduate Medical School, London, through the courtesy of Professor D. L. Mollin. The method of vitamin-B $\mathrm{B}_{12}$ assay was that of Mollin and Ross (1957), using Euglena gracilis, while folic acid assays were carried out by employing Lactobacillus casei as a test organism (Waters and Mollin, 1961). An augmented histamine test meal examination was carried out as described by Kay (1953), and the Crosby capsule (Crosby and Kugler, 1957) was used for gastric biopsies.

In order not to miss other causes of vitamin- $B_{12}$ deficiency, the following investigations were also made: a careful dietary survey by a qualified dietitian, examination of stools for ova, cultures of stools, a barium-meal examination with follow-through, a xylosetolerance test, and an estimation of the total fat content of stools for five consecutive days while on a diet containing $75 \mathrm{~g}$. of fat a day.

When all preliminary investigations were, completed, a therapeutic trial with vitamin $B_{12}$ was carried out in each case ; $10 \mu \mathrm{g}$. of vitamin $\mathbf{B}_{12}$ was administered intramuscularly once weekly, the haematological response being charted by means of daily reticulocyte counts and weekly haemoglobin estimations, total red cell counts, and packed cell volumes.

Finally, the absorption of vitamin $B_{12}$ with and without the simultaneous administration of hog intrinsic factor was estimated by Schilling's (1953) method, using ${ }^{58}$ Co-labelled vitamin $B_{12}$. In four patients vitamin- $B_{12}$ absorption with and without the simultaneous administration of intrinsic factor was also determined by the modified faecal excretion technique of Mollin et al. (1957)

* Senior Registrar, Medical Unit, Thomson Road General Hospital,

+ Consultant Physician and Head, Medical Unit, Thomson Road General Hospital, Singapore.

‡ Late Senior Registrar, Medical Unit, Thomson Road General Hospital, Singapore. Present address: Department of Medicine, General Hospital, Singapore.

Senior Pathologist, General Hospital, Singapore.

\$ Senior Pathologist, General Hospital, Singapore. Colonel, R.A.M.C. Lat, Singapore. Present address: The Queen Alexandra Military
pital Hospital, Millbank, London S.W.1. and by a scintillation count over the liver one week after the administration of the test dose of vitamin $B_{1:}$ (Glass et al., 1954).

\section{Clinical Findings}

Of the six patients four were Chinese and two were Tamils, immigrants from the South of India. Four were males and two were females, their ages varying from 50 to 68 years (Table I). Their modes of presentation varied: three complained of pallor and two of progressive breathlessness on exertion; one complained of fever and diarrhoea for a few days and had not noticed his pallor; and two complained of paraesthesiae, weakness of both legs, and unsteadiness of gait. Though three patients had excessive melanotic pigmentation over the face, hands, and soles, only one had noticed this pigmentation.

\begin{tabular}{|c|c|c|c|c|c|}
\hline $\begin{array}{l}\text { Case } \\
\text { No. }\end{array}$ & Race & Age & Sex & Complaints & $\begin{array}{l}\text { Physical } \\
\text { Findings }\end{array}$ \\
\hline 1 & Indian (Tamil) & 62 & M & $\begin{array}{l}\text { Melanotic pigmenta- } \\
\text { tion. Paraesthesiae } \\
\text { in lower limbs. } \\
\text { Sore tongue }\end{array}$ & $\begin{array}{l}\text { Pallor. Glossitis. } \\
\text { Melanotic pigmen- } \\
\text { tation. Subacute } \\
\text { combined degenera- } \\
\text { tion of cord }\end{array}$ \\
\hline 2 & Chines: & 68 & $\mathrm{~F}$ & $\begin{array}{l}\text { Pallor. Exertional } \\
\text { dyspnoea }\end{array}$ & $\begin{array}{l}\text { Pallor. Loss of vibra- } \\
\text { tion sense in lower } \\
\text { limbs }\end{array}$ \\
\hline 3 & Indian (Tami!) & 54 & $M$ & Fever. Diarrhoea & Pallor. Melanotic \\
\hline 4 & Chinese & 68 & $\mathrm{M}$ & Anorexia. Pallor & $\begin{array}{l}\text { Pallor. Melanotic } \\
\text { pigmentation }\end{array}$ \\
\hline 5 & $\ddot{.}$ & $\begin{array}{l}64 \\
50\end{array}$ & $\begin{array}{r}F \\
M\end{array}$ & $\begin{array}{l}\text { Exertional dyspnoca } \\
\text { General weakness. } \\
\text { Pallor. Paraesthe- } \\
\text { siae in lower limbs }\end{array}$ & $\begin{array}{l}\text { Pallor } \\
\text { Pallor. Glossitis. } \\
\text { Subacute combined } \\
\text { degeneration of cord }\end{array}$ \\
\hline
\end{tabular}

Physical examination revealed the presence of moderately severe pallor of the conjunctivae and mucous membranes in all the patients. Three had an even melanotic pigmentation involving the face, particularly the circumoral area, the dorsum and palms of the hands, and the dorsum and soles of the feet. Glossitis was present in only two patients. Abnormal neurological signs were confined to three: an Indian (Case 1) and a Chinese (Case 6) had the classical signs of subacute combined degeneration of the cord in the lower limbs, and a Chinese (Case 2) had loss of vibration sense in the lower limbs.

\section{Results of Investigations}

These results are summarized in Table II. All the patients were anaemic (haemoglobin varied from 4.3 to $6.2 \mathrm{~g} . / 100 \mathrm{ml}$.) with macrocytic well-haemoglobinized red cells, megaloblastic bone marrows, and histamine-fast achlorhydria (Kay, 1953). Serum vitamin-B ${ }_{12}$ levels before treatment were very low, varying from 10 to $40 \mu \mu \mathrm{g} . / \mathrm{ml}$. The serum folic acid levels, which were estimated simultaneously, were normal, and varied from 4.5 to $25.1 \mathrm{~m} \mu \mathrm{g} . / \mathrm{ml}$.

Gastric biopsies in five patients revealed severe atrophic gastritis ; the sixth patient refused consent for a biopsy. The results of the Schilling tests confirmed the diagnosis of pernicious anaemia in these patients. Absorption of vitamin $B_{12}$ 
was negligible in the absence of intrinsic factor, but was enhanced to a normal range by the simultaneous administration of intrinsic factor. None of the patients had any renal dysfunction which would have rendered the Schilling test unreliable. However, in four patients the absorption of ${ }^{58} \mathrm{Co}$-labelled vitamin $B_{12}$ was also determined by the faecal excretion technique of Mollin et al. (1957) and the hepatic uptake method of Glass et al. (1954), and the results obtained confirmed those obtained by Schilling's method. Finally no evidence of malabsorpticn was found in any of the patients. Microscopical examinations and cultures of the stools, fat content of the stools, xylose-absorption tests, and barium studies were all normal.

\section{Response to Vitamin-B $B_{12}$ Therapy}

After completing investigations, $10 \mu \mathrm{g}$. of vitamin $\mathrm{B}_{12}$ was administered intramuscularly weekly. All six patients responded with a reticulocytosis, the peak reticulocyte count varying from 14 to $23 \%$ and occurring on the fifth to the sixth day after the first dose of vitamin $B_{12}$. Two patients (Cases 1 and 6)
The evidence thus far does indicate that pernicious anaemia of the Addisonian type is uncommon among Asians. This, however, may not be a true evaluation for the future. It remains to be seen whether an increasing awareness of its occurrence and the availability of the more recent tools of investigation-for example, radioactive vitamin $B_{12}$ and its absorption tests-will alter the present concept of its rarity among Asians.

The six cases described in this paper formed part of the group of 40 consecutive cases of megaloblastic anaemia mentioned above. Of the remaining 34 patients, 30 were found to have nutritional folic-acid deficiency, two were vegans suffering from nutritional vitamin- $B_{12}$ deficiency, and two had a haemolytic anaemia complicated by secondary folic-acid deficiency. On the basis of our experience with this group of patients we can conclude that though the majority of Asians with megaloblastic anaemia in Singapore suffer from nutritional folic-acid deficiency, there is yet a distinct minority who suffer from pernicious anaemia and who need specific vitamin- $\mathbf{B}_{12}$ therapy. Four of our six pernicious anaemia patients were Chinese, and belonged to a racial group which forms $70 \%$ of the total population of the State of Singapore. The remain-

TABLE II.-Results of Investigations

\begin{tabular}{|c|c|c|c|c|c|c|c|c|c|c|c|c|c|}
\hline \multirow{2}{*}{$\begin{array}{l}\text { Case } \\
\text { No. }\end{array}$} & \multicolumn{2}{|c|}{ Peripheral Blood } & \multirow{2}{*}{$\begin{array}{l}\text { Megalo- } \\
\text { blastic } \\
\text { Marrow }\end{array}$} & \multirow{2}{*}{$\begin{array}{c}\text { Serum } \\
\text { Iron } \\
(\mu \mathrm{g} \cdot / \\
100 \mathrm{ml} .)\end{array}$} & \multirow{2}{*}{ 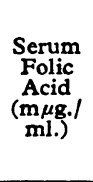 } & \multirow{2}{*}{$\begin{array}{c}\text { Serum } \\
\mathrm{B}_{12} \\
(\mu \mu \mathrm{g} . / \\
\mathrm{ml} .)\end{array}$} & \multirow{2}{*}{$\begin{array}{c}\text { Urinary } \\
\text { Excretion of } \\
\text { Oral s8Co B12 } \\
\text { without Intrin- } \\
\text { sic Factor } \\
\text { (Schilling's } \\
\text { Test) }\end{array}$} & \multirow{2}{*}{$\begin{array}{c}\text { Urinary } \\
\text { Excretion of } \\
\text { Oral \&8Co B B } \\
\text { with Intrin- } \\
\text { sic Factor } \\
\text { (Schilling's } \\
\text { Test) }\end{array}$} & \multirow{2}{*}{$\begin{array}{c}\text { Oral }{ }^{88} \text { Co } B_{12} \\
\text { Absorption } \\
\text { without Intrin- } \\
\text { sic Factor } \\
\text { (Faecal Excre- } \\
\text { tion Method } \\
\text { and Hepatic } \\
\text { Uptake) }\end{array}$} & \multirow{2}{*}{$\begin{array}{c}\text { Oral }{ }^{58} \text { Co } B_{12} \\
\text { Absorption } \\
\text { with Intrin- } \\
\text { sic Factor } \\
\text { (Faecal Excre- } \\
\text { tion Method } \\
\text { and Hepatic } \\
\text { Uptake) }\end{array}$} & \multirow{2}{*}{$\begin{array}{c}\text { Histamine- } \\
\text { fast } \\
\text { Achlor- } \\
\text { Hydria }\end{array}$} & \multirow{2}{*}{$\begin{array}{l}\text { Gastric } \\
\text { Biopsy }\end{array}$} & \multirow{2}{*}{$\begin{array}{c}\text { Reticu- } \\
\text { locyte } \\
\text { Peak after } \\
\text { Intra- } \\
\text { muscular } \\
\text { Vitamin } \\
\text { B }_{12}\end{array}$} \\
\hline & $\mid \underset{\mathrm{g} . / 100 \mathrm{ml} .)}{\mathrm{Hb}}$ & $\begin{array}{l}\text { Macro- } \\
\text { cytosis }\end{array}$ & & & & & & & & & & & \\
\hline $\begin{array}{l}1 \\
2\end{array}$ & $\begin{array}{l}4 \cdot 7 \\
4 \cdot 9\end{array}$ & + & + & $\begin{array}{l}123 \\
130\end{array}$ & $10^{8 \cdot 7}$ & $\begin{array}{l}40 \\
20\end{array}$ & $1 \%$ & $22 \%$ & $\begin{array}{l}\text { Not done } \\
\text { Not done }\end{array}$ & $\begin{array}{l}\text { Not done } \\
\text { Not done }\end{array}$ & + & $\begin{array}{l}\text { Not done } \\
\text { Severe } \\
\text { atrophic }\end{array}$ & $\begin{array}{l}16 \% \\
14 \%\end{array}$ \\
\hline $\begin{array}{l}3 \\
4 \\
5 \\
6\end{array}$ & $\begin{array}{l}4 \cdot 7 \\
4 \cdot 3 \\
6 \cdot 2 \\
6\end{array}$ & $\begin{array}{l}+ \\
+ \\
+\end{array}$ & $\begin{array}{l}+ \\
+ \\
+\end{array}$ & $\begin{array}{l}143 \\
220 \\
150 \\
230\end{array}$ & $\begin{array}{r}4 \cdot 5 \\
5 \cdot 1 \\
14 \cdot 8 \\
25 \cdot 1\end{array}$ & $\begin{array}{l}15 \\
30 \\
40 \\
10\end{array}$ & $\begin{array}{l}1.5 \% \\
0.25 \% \\
3 \% \\
1.8 \%\end{array}$ & $\begin{array}{l}18 \% \\
21 \% \\
30 \% \\
11 \%\end{array}$ & $\begin{array}{c}3.5 \% \\
4 \% \\
15 \% \\
3 \%\end{array}$ & $\begin{array}{l}64 \cdot 2 \% \\
53 \% \\
72 \% \\
49 \%\end{array}$ & $\begin{array}{l}+ \\
+ \\
+ \\
+\end{array}$ & $\begin{array}{c}\text { gastritis } \\
\text { ", } \\
\text { ", }\end{array}$ & $\begin{array}{l}23 \% \\
14 \% \\
14 \% \\
20 \%\end{array}$ \\
\hline
\end{tabular}

who presented with subacute combined degeneration of the cord improved rapidly with specific therapy. The other four remained well on maintenance vitamin $B_{12}$ therapy.

\section{Discussion}

Pernicious anaemia of the Addisonian type is probably rare among Asians, though reports of its occurrence can be found in the literature. Friedlander (1934) discussed the racial incidence of the disorder and noted its rarity in Negroes and even in the dark-skinned white races-for example, Italians and Greeks. Das Gupta and Chatterjea (1951) reviewed Indian publications and found a few reports (Taylor and Chitkara, 1940 ; Chhuttani, 1948); in the same article they described three well-documented cases of megaloblastic erythropoiesis, achlorhydria, and subacute combined degeneration of the cord improving after treatment with crude liver extract. These three patients, they stated, were found " after a careful examination of a very large number of Indian patients with macrocytic anaemia during a period of 15 years." Since then a few more instances have been added in publications from India; Konar (1951) and Misra and Singh (1961) each described one case.

The paucity of reports (in English) of pernicious anaemia in Chinese patients is even more pronounced. Morris (1929) found six cases in the hospital records of Central and North China, but these were not documented, and in his own experience there were no proved cases. Yang and Keefer (1931) reported on two cases of pernicious anaemia in Chinese living in the U.S.A. Both were cases of Minot's and apparently were typical. Schwartz and Rappolt (1945) described three Chinese who suffered from this condition in Chicago; the diagnosis was made on clinical grounds and a satisfactory response to administration of liver extract. ing two patients were South Indian Tamils belonging to a racial group which forms $6 \%$ of the total population of the State. Another noteworthy feature was that three of the six patients-two Indians and one Chinese-had marked melanotic pigmentation of the face, particularly the circumoral area, the palms and dorsum of the hands, and the dorsum and soles of the feet. The pigmentation gradually disappeared approximately four to six weeks after the administration of vitamin $B_{12}$. Cases of pernicious anaemia are commonly described as presenting with pallor and a lemon-yellow tint of the skin. However, a minority may have excessive melanotic pigmentation. Sir William Osler (1916) mentions that there might be "a brownish tinge of the skin (sometimes associated with leucoderma) deep enough to suggest Addison's disease." Though Baker et al. (1963) described similar pigmentation in patients with nutritional vitamin- $B_{12}$ deficiency, it is worth reiterating its occasional presence in patients suffering from pernicious anaemia also.

\section{Summary}

During a period of three and a half years six cases of pernicious anaemia in Asians were detected among routine admissions to a local medical unit in Singapore. Four were Chinese and two were Indians, and in all six the criteria for a diagnosis of pernicious anaemia were fulfilled. All made an excellent response to vitamin- $\mathrm{B}_{12}$ therapy.

We are grateful to Professor D. L. Mollin for carrying out the vitamin-B $B_{12}$ and folic-acid assays. We wish to thank Major G. Vasey, R.A.M.C., and Mr. John Baxter, of the Radioisotope Diagnostic Laboratory, British Military Hospital, Singapore, for carrying out the vitamin- $\mathrm{B}_{12}$ absorption tests. We are indebted to 
Mr. V. Jayasekeran, of the Haematology Laboratory, Thomson Road General Hospital, Singapore, for carrying out most of the routine haematological investigations on our patients.

\section{REFERENCES}

Baker, S. J., Ignatius, M., Johnson, S., and Vaish, S. K. (1963). Brit. med. $\mathcal{J}_{\text {., }} 1,1713$.

Chhuttani, P. N. (1948). Indian med. Gaz., 83, 508

Crosby, W. H., and Kugler, H. W. (1957). Amer. F. dig. Dis., 2, 236.

Das Gupta, C. R., and Chatterjea, J. B. (1951). Blood, 6, 631

Friedlander, R. D. (1934). Amer. F. med. Sci., 187, 634.

Glass, G. B. J., Boyd, L. J., Gellin, G. A., and Stephanson, L. (1954). Arch. Biochem., 51, 251.
Kay, A. W. (1953). Brit. med. 7., 2, 77.

Konar, N. R. (1951). Indian med. Gaz., 86, 237.

Misra, S. S., and Singh, B. N. (1961). 7. Indian med. Ass., 36, 105. Mollin, D. L., Booth, C. C., and Baker, S. J. (1957). Brit. F. Haemat., 3,412 .

and Ross, G. I. M. (1957). Vitamin $B_{12}$ and Intrinsic Factor, edited

by H. C. Heinrich, p. 413 . Stuttgart.
Morris, H. H. (1929). China med. $7 ., 43,768$.

Osler, William (1916). The Principles and Practice of Medicine, 8th ed. p. 736. London.

Schilling, R. F. (1953). f. Lab. clin. Med., 42, 860.

Schwartz, S. O., and Rappolt, L. A. (1945). Arch. intern. Med., 75, 404

Taylor, G. F., and Chitkara, N. L. (1940). Indian med. Gaz., 75, 16.

Waters, A. H., and Mollin, D. L. (1961). J. clin. Path., 14, 335.

Yang, C. S., and Keefer, C. S. (1931). Nat. med. 7. China, 17, 218.

\title{
Effects of Rabies Vaccine in Man
}

\author{
J. C. M. SHARP,* M.B., CH.B., D.P.H. ; SHEILA MCDONALD, $\dagger$ M.D.
}

Brit. med. F., 1967, 3, 20-21

Few opportunities are available in the United Kingdom to study the effects of rabies vaccine in man. Immunization is restricted to those exposed to a definite risk of infection as the course is prolonged, is painful, and may be associated with complications such as peripheral neuritis, dorsolumbar myelitis, and acute ascending Landry type myelitis; major paralytic incidents develop in about 1 in 6,000 persons given treatment (Parish and Cannon, 1962).

In 1965 an opportunity arose in Edinburgh to study the effects of the Semple vaccine, a killed virus suspension of rabbit origin, which was used to immunize 20 persons who had been exposed to infection from a rabid leopard cub.

\section{Epidemiological History}

On 30 October 1965 a 3-month-old leopard arrived at Edinburgh Zoo by air from Nepal. On arrival the animal was emaciated and attempts to force-feed it failed. The animal's condition deteriorated and four days later it was transferred to the Royal (Dick) Veterinary College in Edinburgh, where it died the next day. Encephalitis was found at post-mortem examination and inclusion bodies in the brain tissue suggested the diagnosis of rabies. The animal's head was sent to the Central Veterinary Laboratory, Weybridge, Surrey, for further examination.

At the zoo it was found that four adults (A, B, C, and D) and three children (E, F, and $G$ ) had received bites, scratches, and licks from the leopard (Table I). Three adults (A, B, and $C)$ and one child (E) who had been bitten on their hands were given a single dose of antiserum and with the others were started on a 14-day course of Semple vaccine before rabies was confirmed. One week later a further five persons $(H, I, J$,

- Senior Medical Officer, Health and Social Services Department, Edinburgh.

t Lecturer in Bacteriology, University of Edinburgh.
$\mathrm{K}$, and L) admitted contact with the leopard and were also given vaccine. Four were employees of British European Airways at Edinburgh Airport, who had allowed the animal to lick their abraded hands. The fifth (L) had fed the animal at the zoo but had later left for other employment.

On 2 December the laboratory at Weybridge confirmed the diagnosis of rabies after mice inoculation tests. It was then decided to vaccinate eight other persons who had been at some risk. Four (M, N, O, and P) were zoo employees who had not previously admitted their contact with the animal. The others were a kennel maid (Q) and three veterinary surgeons (R, S, and T) at the Royal (Dick) Veterinary College, who had had their scratched hands in the animal's mouth. The four contacts (A, B, C, and E) most seriously at risk and one other (D) were given further treatment. Four (A, B, D, and E) were given six additional doses of vaccine, but $C$, who became unwell, received only four doses. The first four doses were given daily, beginning one week after completion of the original 14-day course; the remaining two booster doses were given to $\mathrm{A}, \mathrm{B}, \mathrm{D}$, and $\mathrm{E}$ at 10 -day intervals.

Three other persons had been in contact with the animal, but as they had not been bitten, scratched, or licked, no vaccine was given. In all, 20 persons were vaccinated $(12$ males and 8 females). Their ages ranged from 8 to 59 .

\section{The Vaccine and its Administration}

The vaccine, obtained from the Lister Institute of Preventive Medicine, Elstree, Herts, was a sterile preparation of killed rabies virus in $0.5 \%$ phenolized saline containing a $4 \%$ suspension of the brains of rabbits that had died after inoculation with " fixed" rabies virus. Graded doses were given, varying from 2 to $4 \mathrm{ml}$. for the adults and from 1.5 to $2.5 \mathrm{ml}$. for the children. The daily injections were made subcutaneously into alternate sides of the anterior or lateral abdominal wall. All

TABle I.-Prophylactic Treatment Given to Persons At Risk in Relation to the Extent of their Exposure to Infection

\begin{tabular}{|c|c|c|c|c|c|c|c|c|c|c|c|c|c|c|c|c|c|c|c|c|}
\hline \multirow[b]{2}{*}{ Contact: } & \multicolumn{7}{|c|}{ Group at Greater Risk } & \multicolumn{13}{|c|}{ Group at Lesser Risk } \\
\hline & A & B & C & D & $\mathbf{E}$ & $\mathbf{F}$ & G & $\mathbf{H}$ & $\mathbf{I}$ & $\mathbf{J}$ & $\mathbf{K}$ & $\mathbf{L}$ & M & $\mathrm{N}$ & 0 & $\mathbf{P}$ & Q & $\mathbf{R}$ & $\mathbf{s}$ & $\mathbf{T}$ \\
\hline $\begin{array}{c}\text { Degree of exposure to } \\
\text { infection . } \\
\text { Antiserum given } \\
\text { Volume of vaccine } \\
\text { given (ml.) }\end{array}$ & $\begin{array}{c}\text { BL } \\
+ \\
66\end{array}$ & $\begin{array}{c}\text { BL } \\
+ \\
66\end{array}$ & $\begin{array}{l}\text { B } \\
+ \\
58\end{array}$ & $\frac{S}{66}$ & $\begin{array}{l}\text { B } \\
+ \\
42\end{array}$ & $\begin{array}{l}\text { SL } \\
29\end{array}$ & $\begin{array}{l}\text { SL } \\
29\end{array}$ & $\underline{L}$ & $\underline{\mathbf{L}}$ & $\underline{\mathbf{L}}$ & $\underline{\mathbf{L}}$ & s & 1 rece & ed $4 !$ & $\underline{L}$ & $\underline{L}$ & $\stackrel{\mathrm{H}}{-}$ & $\stackrel{\mathrm{H}}{-}$ & $\stackrel{\mathrm{H}}{-}$ & $\stackrel{\mathrm{H}}{-}$ \\
\hline
\end{tabular}

